\title{
ENVIRONMENTAL CONTAMINATION OF HEAVY METALS IN SOME DRIED FISH OF COASTAL REGIONS OF BANGLADESH
}

\author{
Suny Akter ${ }^{1}$, Zeenath Fardous, Jesmin Aktar², Md. Abdur Rahman, \\ Muhammed Alamgir Zaman Chowdhury, Shilpi Sarkar ${ }^{1}$ and Md. Baki Billah ${ }^{1 *}$ \\ Institute of Food and Radiation Biology, AERE, Bangladesh Atomic Energy \\ Commission, Ganakbari, Savar, Dhaka-1349, Bangladesh.
}

\begin{abstract}
Heavy metals are non-biodegradable substances which cause serious carcinogenic effects on animals and humans. As fish occupy top position of aquatic food chain, it is a major source of heavy metal contamination. The concentration of $\mathrm{Cd}, \mathrm{Cr}, \mathrm{Pb}, \mathrm{Mn}, \mathrm{Fe}, \mathrm{Cu}$, and $\mathrm{Zn}$ were $0.0156-0.1428,0.163$ 8.53, $0.0924-0.4026,9.38-65.9382,0.0473-0.1981$ and $0.1473-1.8148 \mathrm{ppm}$ respectively for the fish samples of Cox's Bazar region while 0.0191 - 0.1386, $0.8445-0.1743,0.102-0.4625,0.102-0.4675,9.7269-60.5267,0.3108-$ $0.046 \mathrm{ppm}$ for the fish samples of Saint Martin's region. Comparatively high concentrations of heavy metals were found to be accumulated in Mola (Amblypharyngodon mola), Rupchanda (Stromateus chinensis) and Chhuri (Trichiurus lepturus). The order of heavy metal concentrations were $\mathrm{Fe}>\mathrm{Zn}>\mathrm{Cr}>$ $\mathrm{Cu}>\mathrm{Mn}>\mathrm{Cd}$. The concentration of heavy metals varied from species to species and most of the metals were not significantly correlated, even some metals showed negative correlation among them. Concentration of $\mathrm{Fe}$ in some fishes (Mola, Rupchanda and Chhuri) was found higher than WHO guideline values, while other metals exhibited the value below the WHO standard. The results of this study will assist in acquiring information about the level of toxic metals in these regions and to improve the coastal management in these areas in future.
\end{abstract}

Key words: Pollution, heavy metals, dried fish, coastal regions

\section{INTRODUCTION}

Fish is a valuable and cheap source of protein to man and dried marine fish has been a favored delicacy option especially in Bangladesh. Bangladesh is a tide delta with a $710 \mathrm{~km}$ coast along the Bay of Bengal with one of the richest continental shelf zones of the world. The marine environment of Bangladesh is an important issue in the context of ecological disturbances and climate change.

The Bay of Bengal has the potential for its vast coastal communities and diversity is now subjected to different anthropogenic pollutants (Hossain et al. 2018). The rapid development of industrialization has resulted in heavy metal pollution in our coastal water bodies, which is a significant environmental hazard for invertebrates, fish and humans (Uluturhan and Kucuksezgin 2007). Coastal areas are the most pollution prone zones around the world. The coast of

*Author for correspondence: <bakibillah29@gmail.com>. 1Department of Zoology, Jahangirnagar University, Savar, Dhaka-1342, Bangladesh. ${ }^{2}$ Department of Biology, Savar Government College, Savar, Dhaka, Bangladesh.

(C2019 Zoological Society of Bangladesh DOI: https://doi.org/10.3329/bjz.v47i2.44340 
Bangladesh is known as a zone of multiple vulnerabilities due to various forms of pollution which made the whole coastal and marine environment vulnerable (Islam et al. 2015). The marine and coastal pollution emerges mainly from the ships, industrial effluents, sewerage discharge, untreated effluents, e-waste and open dumping. The precipitation funnels the pollutants into the open sea and finally deposit into sediment. During flood events or current, the sediments release pollutants into water column and finally affect the health of the ocean.

In a food chain fish are important component to transfer heavy metals from one tropic level to another. The heavy metals from the marine environment bioaccumulate in fish and finally get a way to human body causing serious health hazards.

Numerous studies have been carried out on metal pollution in different species of edible fish (Rahman et al. 2012, Amundsen 1997). Heavy metals like $\mathrm{Pb}$ and $\mathrm{Cd}$, are non-essential metals, may exhibit extreme toxicity, even in trace concentrations under certain conditions, require regular monitoring of sensitive aquatic environments (Cid et al. 2001). Thus, only three metals, $\mathrm{Pb}, \mathrm{Cd}$ and $\mathrm{Hg}$, have been included in the regulations of the European Union for hazardous metals (EU 2008). Metals such as $\mathrm{Cu}$ and $\mathrm{Zn}$ are essential metals, since they play an important role in biological systems. The heavy metals with known deleterious effects should fully exclude from the food for human consumption. In this present study, authors investigated the concentrations of $\mathrm{Pb}, \mathrm{Cd}, \mathrm{Cr}, \mathrm{Mn}$, $\mathrm{Fe}, \mathrm{Cu}$ and $\mathrm{Zn}$ in different species of dried fish such as Chhuri (Trichiurus lepturus), Lauita (Harpodon nehereus), Mola (Amblypharyngodon mola), Gonia (Chandramara chandramara), Sundori (Nemipterus vigatus), Bashpati (Devario devario) and Rupchanda (Stromateus chinensis) collected from different fish markets of Cox's Bazar and Saint Martin's regions.

As dried fish occupy a distinct place as a delicacy in Bangladesh dishes and technologies in harvesting, and processing remains crude, there is need to assess their probable contamination with heavy metals as well as the risk associated with their consumption. Several works on heavy metal contamination have been carried out (Ali et al. 2016. Ahmad et al. 2010, Rahman et al. 2012, Begum et al. 2013). But limited information is available on heavy metal contamination in costal dried fish species. The present study investigates the state of heavy metal pollution in dried fish species in coastal regions and provides necessary information regarding the safety of dried fish to achieve food security. 


\section{MATERIAL AND METHODS}

Dried fish samples were collected from the local fish markets of Cox's Bazar and St. Martin's Regions. It is located $150 \mathrm{~km}$ south of the industrial port Chittagong. St. Martin's regions are a small region in the north eastern part of the Bay of Bengal, about $9 \mathrm{~km}$ south of the tip of the Cox's Bazar-Teknaf peninsula, and forming the southern-most part of Bangladesh.

Traditionally dried marine fishes such as Chhuri (Trichiurus lepturus), Lauita (Harpodon nehereus) and Mola (Amblypharyngodon mola), Gonia (Chandramara chandramara), Sundori (Nemipterus vigatus), Bashpati (Devario devario), Rupchanda (Stromateus chinensis) were collected from the local markets of Cox's Bazar and Saint Martin's Regions (Fig. 1). Prior to sampling the polyethylene bags were washed with $1 \mathrm{M} \mathrm{HNO}_{3}$ solution and rinsed thoroughly with distilled water. The samples were properly labelled and preserved at $-20^{\circ} \mathrm{C}$ to avoid the risk of hydrolysis and oxidation.
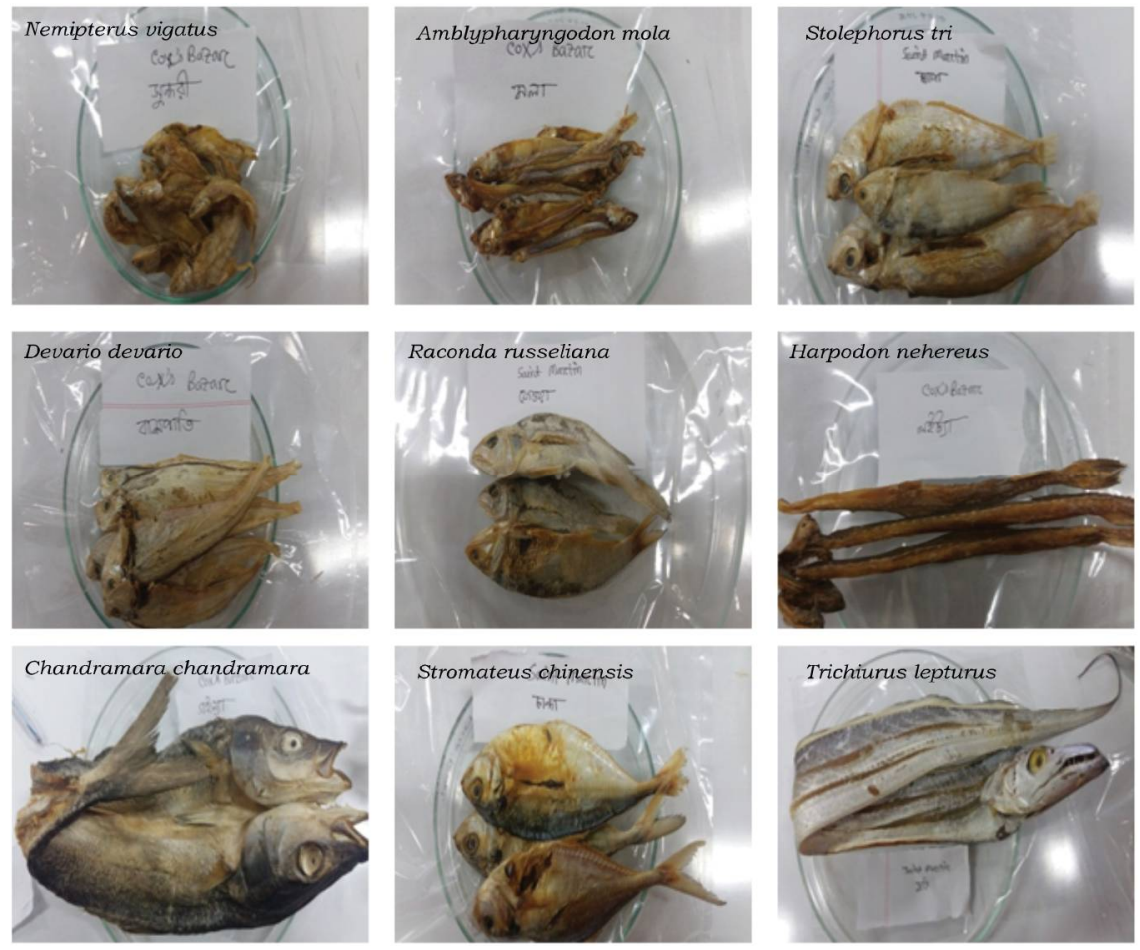

Fig. 1. Dried fish samples collected from different markets of Cox's Bazar and Saint Martin's regions.

The preserved dried fish samples were further dried under the sun for $2-4$ days to remove water and then cut into small pieces followed by grinding. Dried fish samples were digested with concentrated $\mathrm{HNO}_{3}$ and concentrated $\mathrm{HCLO}_{4}$ for heavy metal determination. Briefly, about $0.5 \mathrm{~g}$ of each homogenized fish 
samples were measured into separate beaker. Then $8 \mathrm{ml}$ of concentrated $\mathrm{HNO}_{3}$ (65\%) and $4 \mathrm{ml}$ of $\mathrm{HCLO}_{4}(70 \%)$ was added into the beaker. The mixture was mixed gently and allowed to digest on a hot plate in a fume chamber for $2 \mathrm{hrs}$ at $70^{\circ} \mathrm{C}$ until the brown fumes disappeared. The digested samples were filtered through the Whatman filter paper and each solution made up to $50 \mathrm{ml}$ with deionized water and kept ready for Atomic Absorption Spectrophotometer (AAS) (AA-6300, Shmadzu, Japan) analysis.

Spearman's rank correlation matrix was used to calculate the correlation among the heavy metals in fish samples and the differences among the means of concentrations in fishes were analysed by one-way ANOVA, followed by post-hoc test by Dunnett's test.

\section{RESULTS AND DISCUSSION}

Ten species of dried fish collected from Cox's Bazar and Saint Martin's regions were analysed for heavy metals to characterise and evaluate the state of heavy metal contamination. Table 1 showed the concentration of heavy metals $(\mathrm{Cd}, \mathrm{Cr}, \mathrm{Pb}, \mathrm{Cu}, \mathrm{Mn}, \mathrm{Fe}, \mathrm{Zn})$ in the fish samples from Cox's Bazar.

Table 1. Concentration of heavy metals in fish samples collected from different fish markets of Cox's Bazar

\begin{tabular}{|c|c|c|c|c|c|c|c|}
\hline \multirow{2}{*}{$\begin{array}{l}\text { Fish } \\
\text { samples/heavy } \\
\text { metals }\end{array}$} & \multicolumn{7}{|c|}{ Concentration (ppm) } \\
\hline & $\mathrm{Cd}$ & $\mathrm{Cr}$ & $\mathrm{Pb}$ & $\mathrm{Mn}$ & $\mathrm{Fe}$ & $\mathrm{Cu}$ & $\mathrm{Zn}$ \\
\hline Loittya & $\begin{array}{c}0.029 \\
\pm 0.003\end{array}$ & $\begin{array}{r}0.323 \\
\pm 0.09\end{array}$ & BDL & $\begin{array}{c}0.0924 \\
\pm 0.01\end{array}$ & $\begin{array}{c}9.3841 \\
\pm 1.41\end{array}$ & $\begin{array}{l}0.1031 \\
\pm 0.05\end{array}$ & $\begin{array}{c}0.3084 \\
\pm 0.13\end{array}$ \\
\hline Mola & $\begin{array}{r}0.0179 \\
\pm 0.007\end{array}$ & $\begin{array}{c}0.3072 \\
\pm 0.05\end{array}$ & BDL & $\begin{array}{l}0.1105 \\
\pm 0.07\end{array}$ & $\begin{array}{c}52.773 \\
\pm 823\end{array}$ & $\begin{array}{l}0.0473 \\
\pm 0.01\end{array}$ & $\begin{array}{c}0.1473 \\
\pm 0.04\end{array}$ \\
\hline Bashpati & $\begin{array}{c}0.0456 \\
\pm 0.01\end{array}$ & $\begin{array}{l}0.7415 \\
\pm 0.01\end{array}$ & BDL & $\begin{array}{l}0.3196 \\
\pm 0.12\end{array}$ & $\begin{array}{c}20.2737 \\
\pm 3.86\end{array}$ & $\begin{array}{c}0.2167 \\
\pm 0.110\end{array}$ & $\begin{array}{l}1.3373 \\
\pm 0.09\end{array}$ \\
\hline Gonia & $\begin{array}{l}0.0545 \\
\pm 0.02\end{array}$ & $\begin{array}{r}0.3657 \\
\pm 0.06\end{array}$ & BDL & $\begin{array}{c}0.2259 \\
\pm 0.17\end{array}$ & $\begin{array}{l}10.004 \\
\pm 4.95\end{array}$ & $\begin{array}{l}0.2632 \\
\pm 0.05\end{array}$ & $\begin{array}{l}1.8146 \\
\pm 0.08\end{array}$ \\
\hline Sundori & $\begin{array}{l}0.0209 \\
\pm 0.001\end{array}$ & $\begin{array}{c}0.3702 \\
\pm 0.01\end{array}$ & $\begin{array}{l}0.2571 \\
\pm 0.001\end{array}$ & $\begin{array}{l}0.3905 \\
\pm 0.16\end{array}$ & $\begin{array}{c}18.9268 \\
\pm 2.57\end{array}$ & $\begin{array}{c}0.185 \pm \\
0.02\end{array}$ & $\begin{array}{l}1.5708 \\
\pm 0.61\end{array}$ \\
\hline Churi & $\begin{array}{r}0.0156 \\
\pm 0.006\end{array}$ & $\begin{array}{c}0.5502 \\
\pm 0.13\end{array}$ & BDL & $\begin{array}{r}0.4026 \\
\pm 0.153\end{array}$ & $\begin{array}{c}65.9382 \\
\pm 9.35\end{array}$ & $\begin{array}{l}0.1925 \\
\pm 0.06\end{array}$ & $\begin{array}{c}0.1535 \\
\pm 0.05\end{array}$ \\
\hline Chepa & $\begin{array}{l}0.0309 \\
\pm 0.001\end{array}$ & $\begin{array}{c}0.5255 \\
\pm 0.23\end{array}$ & $\begin{array}{r}0.1605 \\
\pm 0.007\end{array}$ & $\begin{array}{c}0.2884 \\
\pm 0.09\end{array}$ & $\begin{array}{c}29.8327 \\
\pm 5.12\end{array}$ & $\begin{array}{c}0.1608 \\
\pm 0.08\end{array}$ & $\begin{array}{r}0.5774 \\
\pm 0.162\end{array}$ \\
\hline Rupchanda & $\begin{array}{c}0.0191 \\
\pm 0.008\end{array}$ & $\begin{array}{c}8.5352 \\
\pm 2.75\end{array}$ & $\begin{array}{c}0.0277 \\
\pm 0.003\end{array}$ & $\begin{array}{r}0.3088 \\
\pm 0.162\end{array}$ & $\begin{array}{c}19.6859 \\
\pm 6.62\end{array}$ & $\begin{array}{l}0.1571 \\
\pm 0.04\end{array}$ & $\begin{array}{c}0.615 \\
\pm 0.164\end{array}$ \\
\hline Fatra & $\begin{array}{l}0.1428 \\
\pm 0.07\end{array}$ & $\begin{array}{r}0.163 \\
\pm 0.08\end{array}$ & $\begin{array}{l}0.0277 \\
\pm 0.003\end{array}$ & $\begin{array}{c}0.2235 \\
\pm 0.05\end{array}$ & $\begin{array}{c}15.5554 \\
\pm 6.43\end{array}$ & $\begin{array}{c}0.1664 \\
\pm 0.08\end{array}$ & $\begin{array}{r}0.9106 \\
\pm 0.231\end{array}$ \\
\hline Phasa & $\begin{array}{r}0.0633 \\
\pm 0.011\end{array}$ & $\begin{array}{l}0.1788 \\
\pm 0.04\end{array}$ & $\begin{array}{l}0.0277 \\
\pm 0.009\end{array}$ & $\begin{array}{l}0.2042 \\
\pm 0.031\end{array}$ & $\begin{array}{l}13.056 \\
\pm 2.72\end{array}$ & $\begin{array}{c}0.1981 \\
\pm 0.02\end{array}$ & $\begin{array}{l}1.7525 \\
\pm 0.94\end{array}$ \\
\hline Standard & $0.1 \mu f / g$ & & $\begin{array}{c}0.30 \\
\mathrm{mg} / \mathrm{kg}\end{array}$ & & $15 \mu g / g$ & & \\
\hline References & EU 2008 & & Eu 2008 & & Tuzen an & Sylak 2007 & \\
\hline
\end{tabular}


Among the fish species high amount of heavy metals were accumulated in Mola (Amblypharyngodon mola), Rupchanda (Stromateus chinensis) and Chhuri (Trichiurus lepturus). Fe was found in greater concentration than that of other heavy metals.

Among the 7 heavy metals in dried fishes from Cox's Bazar and Saint Martin's regions, $\mathrm{Fe}$ was the highest and $\mathrm{Cd}$ was the lowest, while $\mathrm{Zn}, \mathrm{Cr}, \mathrm{Cu}$ and $\mathrm{Mn}$ were moderate in concentration and $\mathrm{Pb}$ was found lower the detection limit (LOD).

Loittya fish: For Cox's Bazar samples, Fe and Cd concentration were 9.384 and 0.0291ppm while for the samples from Saint Martin's regions, Fe and Cd concentration were 12.9677 and $0.026 \mathrm{ppm}$, respectively (Tables 1 and 2). In fish from both regions, the concentration hierarchy of the heavy metals were Fe $>\mathrm{Zn}>\mathrm{Cr}>\mathrm{Cu}>\mathrm{Mn}>\mathrm{Cd}>\mathrm{Pb}$ (Tables 1 and 2).

Table 2. Concentration of heavy metals (Mean \pm Sd) in fish samples collected from different fish markets of Saint Martin's regions

\begin{tabular}{|c|c|c|c|c|c|c|c|}
\hline \multirow{2}{*}{$\begin{array}{l}\text { Fish } \\
\text { samples/ } \\
\text { Heavy metals }\end{array}$} & \multicolumn{7}{|c|}{ Concentrations (ppm) } \\
\hline & $\mathrm{Cd}$ & $\mathrm{Cr}$ & $\mathrm{Pb}$ & $\mathrm{Mn}$ & $\mathrm{Fe}$ & $\mathrm{Cu}$ & $\mathrm{Zn}$ \\
\hline \multirow[t]{2}{*}{ Loittya } & 0.0226 & 0.3117 & BDL & 0.102 & 12.9677 & 0.0566 & 0.194 \\
\hline & \pm 0.03 & \pm 0.09 & & \pm 0.03 & \pm 0.02 & \pm 0.02 & \pm 0.01 \\
\hline \multirow[t]{2}{*}{ Mola } & 0.0232 & 0.314 & BDL & 0.4675 & 9.7269 & 0.0454 & 0.311 \\
\hline & \pm 0.06 & \pm 0.01 & & \pm 0.02 & \pm 0.01 & \pm 0.01 & \pm 0.04 \\
\hline \multirow[t]{2}{*}{ Bashpati } & 0.0597 & 0.7505 & BDL & 0.3316 & 21.0573 & 0.2167 & 1.424 \\
\hline & \pm 0.005 & \pm 0.02 & & \pm 0.033 & \pm 0.014 & \pm 0.45 & \pm 0.05 \\
\hline \multirow[t]{2}{*}{ Gonia } & 0.0256 & 0.746 & $\mathrm{BDL}$ & 0.3268 & 21.0084 & 0.2092 & 1.394 \\
\hline & \pm 0.01 & \pm 0.02 & & \pm 0.022 & \pm 0.01 & \pm 0.32 & \pm 0.3 \\
\hline \multirow[t]{2}{*}{ Sundori } & 0.0592 & 0.4872 & 0.2692 & 0.3833 & 19.1961 & 0.2297 & 1.791 \\
\hline & \pm 0.06 & \pm 0.03 & \pm 0.02 & \pm 0.014 & \pm 0.013 & \pm 0.52 & \pm 0.04 \\
\hline \multirow[t]{2}{*}{ Churi } & 0.0191 & 0.539 & 0.1243 & 0.3917 & 20.5267 & 0.3172 & 1.56 \\
\hline & 0.03 & \pm 0.012 & \pm 0.03 & \pm 0.02 & \pm 0.014 & \pm 0.04 & \pm 0.006 \\
\hline \multirow[t]{2}{*}{ Chepa } & 0.0226 & 0.196554 & 0.2088 & 0.2944 & 301103 & 0.1013 & 0.605 \\
\hline & \pm 0.06 & \pm 0.3 & \pm 0.013 & \pm 0.05 & \pm 0.01 & \pm 0.01 & \pm 0.14 \\
\hline \multirow[t]{2}{*}{ Rupchanda } & 0.0221 & 0.1743 & 0.4625 & 0.2968 & 30.3143 & 0.2278 & 0.599 \\
\hline & \pm 0.022 & \pm 0.015 & \pm 0.03 & \pm 0.01 & \pm 0.04 & \pm 0.05 & \pm 0.05 \\
\hline \multirow[t]{2}{*}{ Fatra } & 0.1339 & 0.1968 & 0.397 & 0.2078 & 16.4778 & 0.5108 & 0.928 \\
\hline & \pm 0.011 & \pm 0.023 & \pm 0.011 & \pm 0.012 & \pm 0.03 & \pm 0.11 & \pm 0.35 \\
\hline \multirow[t]{2}{*}{ Phasa } & 0.1386 & 0.84452 & 0.4021 & 0.2114 & 16.0778 & 0.1161 & 0.496 \\
\hline & \pm 0.07 & \pm 0.05 & \pm 0.034 & \pm 0.02 & \pm 0.055 & \pm 0.54 & \pm 0.44 \\
\hline Standard & \multicolumn{2}{|l|}{$0.1 \mu \mathrm{g} / \mathrm{g}$} & \multicolumn{2}{|l|}{$\begin{array}{l}0.30 \\
\mathrm{mg} / \mathrm{kg}\end{array}$} & \multicolumn{3}{|l|}{$15 \mu \mathrm{g} / \mathrm{g}$} \\
\hline References & \multicolumn{2}{|l|}{$\begin{array}{l}\text { EU } \\
2008 \\
\end{array}$} & \multicolumn{2}{|l|}{ EU 2008} & \multicolumn{3}{|c|}{ Tuzen and Sylak 2007} \\
\hline
\end{tabular}

Mola fish: In Cox's Bazar samples, the highest amount of Fe (52.773 ppm) and the lowest $\mathrm{Cd}(0.0179 \mathrm{ppm})$ was found. The concentration of $\mathrm{Pb}$ was below the detection level. The concentration hierarchy of the heavy metals were $\mathrm{Fe}>\mathrm{Cr}$ 
$>\mathrm{Zn}>\mathrm{Mn}>\mathrm{Cu}>\mathrm{Cd}>\mathrm{Pb}$, respectively. Similarly, samples from Saint Martin's regions exhibited the highest amount of $\mathrm{Fe}(9.7269 \mathrm{ppm})$ and the lowest $\mathrm{Cd}$ (0.0232 ppm) (Tables 1 and 2).

Bashpati fish: Bashpati accumulated the highest amount of Fe (20.2737 ppm) and the lowest Cd (0.0456 ppm) in samples from Cox's Bazar while in samples from Saint Martin's regions Fe was dominant in concentration (21.0573 $\mathrm{ppm})$. In both samples, the concentration hierarchy of heavy metals were Fe > $\mathrm{Zn}>\mathrm{Cr}>\mathrm{Mn}>\mathrm{Cu}>\mathrm{Cd}>\mathrm{Pb}$. Similarly, in both samples the concentration of $\mathrm{Pb}$ was below the detection level (Tables 1 and 2).

Gonia fish: In samples from both Cox's Bazar and Saint Martin's regions, the highest and the lowest concentrations were observed for Fe and Cd, respectively. The concentration of $\mathrm{Pb}$ was below the detection level. The concentration hierarchy of the heavy metals were $\mathrm{Fe}>\mathrm{Zn}>\mathrm{Cr}>\mathrm{Mn}>\mathrm{Cu}>\mathrm{Cd}>\mathrm{Pb}$ (Tables 1 and 2).

Chhuri fish: In samples from both Cox's Bazar and Saint Martin's regions, the highest and the lowest concentrations were observed for $\mathrm{Fe}$ and $\mathrm{Cd}$ respectively. The concentration of $\mathrm{Pb}$ was below the detection level. For Cox's Bazar samples, the concentration hierarchy of the heavy metals were $\mathrm{Fe}>\mathrm{Cr}>$ $\mathrm{Mn}>\mathrm{Cu}>\mathrm{Cd}>\mathrm{Zn}>\mathrm{Pb}$ while for samples from Saint Martin's regions showed the hierarchy of the heavy metals as follows: $\mathrm{Fe}>\mathrm{Zn}>\mathrm{Cr}>\mathrm{Cu}>\mathrm{Mn}>\mathrm{Pb}>\mathrm{Cd}$ (Tables 1and 2).

Sundori fish: In samples from both Cox's Bazar and Saint Martin's regions, the highest and the lowest concentration were observed for $\mathrm{Fe}$ and $\mathrm{Cd}$ respectively. For samples from Cox's Bazar, the concentration hierarchy of the heavy metals were $\mathrm{Fe}>\mathrm{Zn}>\mathrm{Cr}>\mathrm{Mn}>\mathrm{Cu}>\mathrm{Cd}>\mathrm{Pb}$ while for samples from Saint Martin's regions the concentration hierarchy were $\mathrm{Fe}>\mathrm{Zn}>\mathrm{Cr}>\mathrm{Cu}>\mathrm{Mn}$ $>\mathrm{Cd}>\mathrm{Pb}$. The concentration of $\mathrm{Pb}$ was below the detection level in samples from both the regions (Tables 1 and 2).

Chepa fish: In samples from both Cox's Bazar and Saint Martin's regions, the highest and the lowest concentrations were observed for Fe and Cd, respectively. For both the samples from Cox's Bazar, the concentration hierarchy of the heavy metals were $\mathrm{Fe}>\mathrm{Zn}>\mathrm{Cr}>\mathrm{Mn}>\mathrm{Cu}>\mathrm{Pb}>\mathrm{Cd}$, respectively and the concentration of $\mathrm{Pb}$ was below the detection level in samples from both regions (Tables 1 and 2).

Rupchanda fish: In Cox's Bazar samples, the highest amount of Fe (19.6859 $\mathrm{ppm})$ and the lowest amount of $\mathrm{Cd}(0.0191 \mathrm{ppm})$ was found. The concentration hierarchy of the heavy metals were $\mathrm{Fe}>\mathrm{Cr}>\mathrm{Zn}>\mathrm{Mn}>\mathrm{Cu}>\mathrm{Cd}>\mathrm{Pb}$, respectively. Similarly, in samples from Saint Martin's regions exhibited the 
highest amount of $\mathrm{Fe}(53.3143 \mathrm{ppm})$ and the lowest $\mathrm{Cd}(0.0221 \mathrm{ppm})$. The concentration of $\mathrm{Pb}$ was below the detection level in both cases (Tables 1 and 2).

Feowa fish: In Cox's Bazar samples, Feowa accumulated the highest amount of $\mathrm{Fe}(15.5554 \mathrm{ppm})$ and the lowest $\mathrm{Cd}(0.1428 \mathrm{ppm})$. The concentration hierarchy of the heavy metals were $\mathrm{Fe}>\mathrm{Zn}>\mathrm{Cr}>\mathrm{Cu}>\mathrm{Mn}>\mathrm{Cd}>\mathrm{Pb}$, respectively in case of Feowa dried fish. Again Feowa fish collected from Saint Martin's regions showed the highest amount of Fe (16.4778 ppm) and the lowest amount of $\mathrm{Cd}(0.01339 \mathrm{ppm})$. The concentration hierarchy of the heavy metals was $\mathrm{Fe}>\mathrm{Zn}>\mathrm{Cu}>\mathrm{Cr}>\mathrm{Mn}>\mathrm{Pb}>\mathrm{Cd}$ (Tables 1 and 2).

Phasa fish: Phasa accumulated the highest amount of Fe (66.7872 ppm) and the lowest $\mathrm{Cd}(0.0633 \mathrm{ppm})$ in case of Cox's Bazar samples. The concentration hierarchy of the heavy metals were $\mathrm{Fe}>\mathrm{Zn}>\mathrm{Cr}>\mathrm{Cu}>\mathrm{Mn}>\mathrm{Cd}>\mathrm{Pb}$. On the other hand, Phasa fish collected from Saint Martin's regions showed that muscle contained the highest amount of Fe (16.0078 ppm) and the lowest $\mathrm{Cu}(0.1161$ $\mathrm{ppm}$ ). The concentration hierarchy of the heavy metals were $\mathrm{Fe}>\mathrm{Cr}>\mathrm{Zn}>\mathrm{Mn}>$ $\mathrm{Cd}>\mathrm{Pb}$ (Tables 1 and 2).

Correlation matrix of heavy metals in dried fish from Cox's Bazar and Saint Martin's regions: Pearson's correlations matrix was determined among heavy metals in dried fishes from Cox's Bazar and Saint Martin's region (Tables 3 and 4). These correlations of coefficient were calculated among seven metals to identify, where there were presence of positive or negative linear association between metals.

Table 3. Correlation matrix among heavy metals in dried fish samples from Cox's Bazar region

\begin{tabular}{llllllll}
\hline & $\mathrm{Cr}$ & $\mathrm{Pb}$ & $\mathrm{Cd}$ & $\mathrm{Cu}$ & $\mathrm{Mn}$ & $\mathrm{Zn}$ & $\mathrm{Fe}$ \\
\hline $\mathrm{Cr}$ & 1.00 & & & & & & \\
$\mathrm{~Pb}$ & 0.0611 & 1.00 & & & & & \\
$\mathrm{Cd}$ & $-0.3752^{*}$ & 0.09990 & 1.00 & & & & \\
$\mathrm{Cu}$ & 0.4109 & 0.1543 & 0.4540 & 1.00 & & & \\
$\mathrm{Mn}$ & $0.7699^{*}$ & $0.7558^{*}$ & 0.2001 & 0.311 & 1.00 & & \\
$\mathrm{Zn}$ & -0.0785 & -0.3036 & 0.0168 & $0.5042^{*}$ & -0.0842 & 1.00 & \\
$\mathrm{Fe}$ & $-0.0842^{*}$ & $0.5957^{*}$ & 0.20036 & 0.2698 & $0.6267^{*}$ & 0.2523 & 1.00 \\
\hline
\end{tabular}

**Correlation is significant at the 0.01 level (2-tailed).

For the samples of Cox's Bazar region, significant positive correlations were found between $\mathrm{Cr}$ and $\mathrm{Mn}$ (0.7699), $\mathrm{Pb}$ and $\mathrm{Mn}$ (0.7558), Fe and $\mathrm{Mn}$ (0.6267), $\mathrm{Pb}$ and $\mathrm{Fe}(0.5957)$ and $\mathrm{Zn}$ and $\mathrm{Cu}(0.5042)$. These metal pairs indicated the similar sources of pollution in dried fish. However, most of the metals in fishes were not significantly correlated even some showed negative correlation, which indicated 
different anthropogenic and natural sources in fish samples (Table 3) while for the samples of Saint Martin's region exhibited significant positive correlations between $\mathrm{Cr}$ and $\mathrm{Cd}$ (0.1723), $\mathrm{Cr}$ and $\mathrm{Fe}$ (0.1843), $\mathrm{Pb}$ and $\mathrm{Mn}$ (0.5327), $\mathrm{Pb}$ and $\mathrm{Fe}$ (0.6261) and $\mathrm{Zn}$ and $\mathrm{Cu}(0.6236)$ (Table 4).

Table 4. Correlation matrix among heavy metals in dried fish samples from Saint Martin's region

\begin{tabular}{llllllll}
\hline & $\mathrm{Cr}$ & $\mathrm{Pb}$ & $\mathrm{Cd}$ & $\mathrm{Cu}$ & $\mathrm{Mn}$ & $\mathrm{Zn}$ & $\mathrm{Fe}$ \\
\hline $\mathrm{Cr}$ & 1.00 & & & & & & \\
$\mathrm{~Pb}$ & -0.2121 & 1.00 & & & & & \\
$\mathrm{Cd}$ & $0.1723^{*}$ & 0.9863 & 1.00 & & & & \\
$\mathrm{Cu}$ & 0.2521 & -0.02543 & 0.651 & 1.00 & & & \\
$\mathrm{Mn}$ & $-0.6542^{*}$ & $0.5327^{*}$ & $-0.1343^{*}$ & -0.421 & 1.00 & & \\
$\mathrm{Zn}$ & 0.0875 & -0.15632 & 0.08763 & $0.62362^{*}$ & -0.0977 & 1.00 & \\
$\mathrm{Fe}$ & $0.1843^{*}$ & $0.6261^{*}$ & 0.07654 & 0.43241 & 0.1372 & 0.0541 & 1.00 \\
\hline
\end{tabular}

**Correlation is significant at the 0.01 level (2-tailed).

$C d$ : Fish samples from Cox's Bazar exhibited the highest concentration of Cd in dried phasa $(0.0633 \mathrm{ppm})$ and the lowest in dried Rupchanda $(0.0156 \mathrm{ppm})$. On the other hand, fishs samples from Saint Martin's region showed the highest concentration of $\mathrm{Cd}$ in dried Phasa $(0.1386 \mathrm{ppm})$ and the lowest concentration in dried Bashpati (0.0597 ppm). In this study, Cd concentrations were lower than those reported earlier (Mendil et al. 2005) in fish from Turkish Lakes. Our research values were found to be lower than the acceptable limit proposed by the (EU 2008 and Batten et al. 1999). The European Community proposed threshold values of metal concentrations in fish muscle of only $0.05 \mu \mathrm{g} / \mathrm{g}$ of Cd. (EC 2006). Cd can be accumulated with metallothioneins and uptake of 3 - 330 $\mathrm{mg} /$ day is toxic and $1.5-9 \mathrm{mg} /$ day is lethal to humans (Mansouri et al. 2013). Cd injures kidneys and causes symptoms of chronic toxicity, including impairment of kidney function, poor reproductive capacity, hypertension, tumours and hepatic dysfunction (Waalkes et al. 2000).

$\mathrm{Cu}$ : In Cox's Bazar samples, the highest concentration of $\mathrm{Cu}$ was found in dried Gonia $(0.1925 \mathrm{ppm})$ and the lowest in dried Mola $(0.0473 \mathrm{ppm})$. On the other hand, samples from Saint Martin's showed the highest concentration of $\mathrm{Cu}$ in dried Feowa $(0.5801 \mathrm{ppm})$ and the lowest in dried Loittya $(0.0566 \mathrm{ppm})$. In our study, $\mathrm{Cu}$ concentrations are lower than the values from earlier reports (Chele et al. 2002). The copper contents in the samples were much less than the FAO-permitted level of $30 \mu \mathrm{g} / \mathrm{g}$. Excessive intake of copper may lead to liver cirrhosis, dermatitis and neurological disorders (Toth et al. 1997). 
$M n$ : The highest concentration of Mn was found in dried Chhuri (0.4026 ppm) and the lowest in dried Loittya (0.0924 ppm) in Cox's Bazar samples while samples from Saint Martin's region exhibited the highest concentration of Mn in dried Mola $(0.4675 \mathrm{ppm})$ and the lowest in dried Loittya $(0.0924 \mathrm{ppm})$. Mn concentrations in all the fishes were lower than the safe limit (1 ppm) recommended by FAO (1983).

$\mathrm{Pb}$ : The highest concentration of $\mathrm{Pb}$ was found in dried Chepa $(0.1056 \mathrm{ppm})$ and the lowest in dried Gonia (0.0277 ppm) in Cox's Bazar samples. On the other hand, samples from Saint Martin's showed the highest concentration of $\mathrm{Pb}$ in dried Rupchanda (0.4625 ppm) and the lowest in dried Bashpati. These levels were found to be lower than $0.30 \mathrm{mg} / \mathrm{kg}$ set by EU (2008) except dried Rupchanda, hence there is a potential risk of $\mathrm{Pb}$ poisoning or toxicity when Rupchanda is consumed. Exposure to $\mathrm{Pb}$ may cause nervous system damage, paralysis and pain in the extremities (Nolan 2003).

$\mathrm{Fe}$ : The highest concentration of $\mathrm{Fe}$ was found in dried Phasa (66.7872 ppm) and the lowest in Loittya $(9.3841 \mathrm{ppm})$ in samples from Cox's Bzar. On the other hand, samples from Saint Martin's region showed the highest concentration of Fe in dried Rupchanda (30.3143 ppm) and the lowest in dried Mola (09.7269). Fe exhibited the positive correlation with $\mathrm{Cr}$ and $\mathrm{Pb}$.

$\mathrm{Zn}$ : The highest concentration of $\mathrm{Zn}$ was found in dried Phasa (1.7525 ppm) and the lowest in Mola (0.1473 ppm). On the other hand, fish samples from Saint Martin's region showed the highest concentration of $\mathrm{Zn}$ in dried Sundhori (1.7914 ppm) and in dried Loittya (0.194 ppm). According to Haque et al. (2003) the maximum permissible $\mathrm{Cu}$ and $\mathrm{Zn}$ levels were $10-100$ and $30-100 \mathrm{mg} / \mathrm{kg}$ for fish respectively. Since the levels of $\mathrm{Cu}$ and $\mathrm{Zn}$ were lower than the maximum permissible levels, it may be concluded that consumption of this species from the coastal region is not a problem for human health.

Cr: Cr concentration varied from 8.5352 to $0.163 \mathrm{ppm}$ in Cox's Bazar samples and the highest concentration was found in dried Rupchanda (0.0633 ppm) and the lowest in dried Feowa (0.0156 ppm). Fishes from Saint Martin's showed the highest concentration of $\mathrm{Cr}$ in dried Phasa (0.84452 ppm) and the lowest concentration in dried Rupchanda $(0.1743 \mathrm{ppm})$. Cr does not normally accumulate in fish and hence low concentration was reported even from the industrialized part of the world. A study reported that the rate of uptake was higher in young fish but the body burden of $\mathrm{Cr}$ declined with the age due to rapid elimination (Datta 1993). In this study the observed concentration level is much lower than the permissible limits of 1-12 ppm recommended by (USFDA, 1993). A significant ( $p$ < 0.05) relationship between Cd levels in fish from Cox's Bazar and Saint Martin's region was found while no significant differences were 
observed in Cr levels in fish from Cox's Bazar and Saint Martin's region. Manganese in fish from Cox's Bazar and Saint Martin's showed significant difference $(\mathrm{p}<0.05)$ while no significant difference was observed in Fe level in fish from Cox's Bazar and Saint Martin's area.

Pravakar et al. (2013) conducted heavy metal investigation on three marine dried fish species. The results showed that concentrations of $\mathrm{Cd}$ and $\mathrm{Cu}$ were $0.28-1.3 \mu \mathrm{g} / \mathrm{g}$ in Chinese Pomfret; 0.71- $2.1 \mu \mathrm{g} / \mathrm{g}$ in Bombay duck and $0.35-4.1$ $\mathrm{\mu g} / \mathrm{g}$ in Ribbon fish indicating the acceptable quality of the traditional marine dried fish products. In the present study, the concentrations of $\mathrm{Cd}$ and $\mathrm{Cu}$ were much lower than the previous reports.

Rahman et al. (2012) worked on concentrations of eight heavy metals (Pb, $\mathrm{Cd}, \mathrm{Ni}, \mathrm{Cr}, \mathrm{Cu}, \mathrm{Zn}, \mathrm{Mn}$, and As) in the muscles of ten species of fish collected from Bangshi river at Savar in Bangladesh and found their concentrations below the safe limit thus there was no indication of pollution.

Raknuzzaman et al. (2016) determined seven trace metal concentrations ( $\mathrm{Cr}$, $\mathrm{Ni}, \mathrm{Cu}, \mathrm{Zn}, \mathrm{As}, \mathrm{Cd}$ and $\mathrm{Pb}$ ) in some commercial fishes and crustaceans collected from coastal areas of Bangladesh. Trace metals in fish samples were in the range of $\mathrm{Cr}(0.15$ - 2.2), Ni (0.1 - 0.56), Cu (1.3 - 1.4), Zn (31-138), As (0.76-13), $\mathrm{Cd}$ (0.033-0.075), and $\mathrm{Pb}(0.07-0.63 \mathrm{mg} / \mathrm{kg}$ wet weight (ww), respectively. Arsenic (13 mg/kg ww) and $\mathrm{Zn} \mathrm{(138} \mathrm{mg/kg} \mathrm{ww)} \mathrm{concentrations} \mathrm{were} \mathrm{remarkably}$ high in fish of Cox's Bazar due to the interference of uncontrolled huge numbers of hatcheries and industrial activities. The elevated concentrations of $\mathrm{Cu}(400)$, $\mathrm{Zn}$ (1480) and As (53 mg/kg ww) were also observed in crabs of Cox's Bazar which was considered as an absolutely discrepant aquatic species with totally different bioaccumulation pattern.

The present study showed that, $\mathrm{Fe}$ was the most and $\mathrm{Cd}$ was the least accumulated metal in the dried fish species from Cox's Bazar and Saint Martin's areas. This pollution may be from industries or from drainage lines which are connected with the Bay of Bengal. There is also a possibility of heavy metal contamination during handling and processing of fish samples. From the human health point of view, this study showed that there were no possible health risks of heavy metal contamination to consumers from the coastal regions of Bangladesh.

\section{CONCLUSIONS}

The concentration of heavy metals in dried fish sample were Cd: $0.0191 \pm$ $0.02-0.0633 \pm 0.001 ; \mathrm{Cr}: 0.163 \pm 0.025-8.5352 \pm 0.03 ; \mathrm{Mn}: 0.0924 \pm 0.002-$ $0.4026 \pm 0.034 ;$ Fe: $9.3841 \pm 0.05-66.7872 \pm 0.01 ; \mathrm{Zn}: 0.1473 \pm 0.065-1.8146$ \pm 0.045 and $\mathrm{Cu}: 0.047 \pm 0.05-0.198 \pm 0.06$. The order of heavy metals in the 
fish samples were $\mathrm{Fe}>\mathrm{Zn}>\mathrm{Cr}>\mathrm{Cu}>\mathrm{Mn}>\mathrm{Cd}>\mathrm{Pb}$. Comparatively high concentrations of heavy metals were found to be accumulated in Mola (Amblypharyngodon mola), Rupchanda (Stromateus chinensis) and Chhuri (Trichiurus lepturus). In almost all the studied fish species, the concentration of $\mathrm{Pb}$ was below the detection limit but the concentration of heavy metals were within the international permissible limit given by WHO/EU except the concentration of $\mathrm{Fe}$ in fish Churi collected from Cox's Bazar and Saint Martin's regions. The findings of the present study indicated that the dried fish samples of the regions under study were safe for human consumption and appeared to be no immediate threat to these fish species from heavy metal contamination. Further investigation on the bioaccumulation and effects of heavy metals on fish and other aquatic biota are required to understand the effects of pollutants in aquatic environment.

\section{LITERATURE CITED}

AHMAD, M.K., ISLAM, S., RAHMAN, M.S., HAQUE, M.R. and ISLAM, M.M. 2010. Heavy metals in water, sediment and some fishes of Buriganga River, Bangladesh. International Journal of Environmental Research 4(2): 321-332.

ALI, M.M., ALI, M.L., ISLAM, M.S. and RAHMAN, M.Z. 2016. Preliminary assessment of heavy metals in water and sediment of Karnaphuli River, Bangladesh. Environmental Nanotechnology, Monitoring \& Management 5: 27-35.

AMUNDSEN, P.A., STALDVIK, F.J., LUKIN, A.A., KASHULIN, N.A., POPOVA, O.A. and RESHETNIKOV, Y.S 1997. Heavy metal contamination in freshwater fish from the border region between Norway and Russia. Sci. Total. Environ. 201(5): 211-224.

BATTEN, T.F., MOONS, L. and VANDESANDE, F. 1999. Innervation and control of the adenohypophysis by hypothalamic peptidergic neurons in teleost fishes: EM immunohistochemical evidence. Microscopy Research and Technique 44(1): 19-35.

BEGUM, A., MUSTAFA, A.I., AMIN, M.N., CHOWDHURY, T.R., QURAISHI, S.B. and BANU, N. 2013. Levels of heavy metals in tissues of Shingi fish (Heteropneustes fossilis) from Buriganga River of Bangladesh. Environmental Monitoring and Assessment 185(7): 5461-5469.

CHALE, F.M.M. 2002. Trace metal concentrations in water, sediments and fish tissue from Lake Tanganyika. Science of the Total Environment 299(1-3): 115-121.

CID, B.P., BOIA, C., POMBO, L. and REBELO, E. 2001. Determination of Clarkson Human toxicology of mercury. J. Trace Elem. Exp. Med. 11: 303-317.

DUTTA, H.M., ADHIKARI, N.K., SINGH, P.K. and MUNSHI, J.S. 1993. Histopathological changes induced by malathion in the liver of a freshwater catfish, Heteropneustes fossilis (Bloch). B. Environ. Contam. Tox. 51: 895-900.

EUROPEAN COMMISSION. 2006. Commission Regulation (EC) No. 1881/2006 of the European parliament and the council of 19 December 2006 setting maximum levels for certain contaminants in foodstuffs. Off. J. Eur. Communities L, 364. 
EUROPEAN UNION. 2008. Commission Regulation (EC) No 629/2008 of 2 July 2008 amending Regulation (EC) No 1881/2006 setting maximum levels for certain contaminants in foodstuffs Official $J$ European Union 173/6-9.

FAO. 1983. Compilation of legal limits for hazardous substances in fish and fishery products. FAO Fish Circular 464: 5-100

HAgUE, W., AHMED, A.T.A., TARAFDAR, S.A., AKHTER, S. and QURAISHI, S.B. 2003. Trace elements in two small fishes (Puntius sophore (Hamilton) and Mystus vittatus (Bloch) of Buriganga River, Balu River and Ichamati beel. Bangladesh J. Zool. 31(2): 247-251.

HOSSAIN, M.A., AHMED, M., OJEA, E. and FERNANDES, J.A. 2018. Impacts and responses to environmental change in coastal livelihoods of south-west Bangladesh. Science of the Total Environment, 637, 954-970.

ISLAM, M.S., AHMED, M.K., RAKNUZZAMAN, M. and HABIBULLAH-AL-MAMUN, M. and ISLAM, M. K. 2015. Heavy metal pollution in surface water and sediment: A preliminary assessment of an urban river in a developing country. Ecological Indicators 48: 282-291.

MANSOURI, N., KHORASANI, N., MONAVARI, S. M., KARBASI, A., and PANAHANDEH, M. 2013. Non-carcinogenic risk estimation of $\mathrm{Cr}, \mathrm{Cd}, \mathrm{Pb}$ in human to fish consumption from Anzali wetland. World Journal of Fish and Marine Sciences, 5(6), 603-610.

MENDIL, D., ULUOZLU, O.D., HASDEMIR, E., TUZEN, M., SARI, H., and SUICMEZ, M. 2005. Food Chemistry, Cellular distribution of $\mathrm{Cu}, \mathrm{Pb}$, and $\mathrm{Zn}$ in the Grey Mangrove Avicemnia marina (Forsk.), Vierh Aquatic Botanic, pp 87-94.

NOLAN, K. 2003. Copper Toxicity Syndrome, J. Orthomol. Psychiatry 12(4): 270-282.

PRAVAKAR, P., MANSUR, M. A. and ASADUZZAMAN, M. 2013. Quality and Safety Aspect of Three Sun-Dried Marine Fish Species: Chinese Pomfret (Stromateus chinensis), Bombay Duck (Harpodon neherius) and Ribbon Fish (Trichiurus haumela). World Journal of Zoology, 8(4): 381387.

RAHMAN, M.S., MOLLA, A.H., SAHA, N. and RAHMAN, A. 2012. Study on heavy metals levels and its risk assessment in some edible fishes from Bangshi River, Savar, Dhaka, Bangladesh. Food Chemistry 134(4): 1847-1854

RAKNUZZAMAN, M., AHMED, M. K., ISLAM, M. S., HABIBULLAH-AL-MAMUN, M., TOKUMURA, M., SEKINE, M., and MASUNAGA, S. 2016. Trace metal contamination in commercial fish and crustaceans collected from coastal area of Bangladesh and health risk assessment. Environmental Science and Pollution Research 23(17): 17298-17310.

TOTH, J.F. and BROWN, R.B. 1997. Racial and gender meanings of why people participate in recreational fishing. Leisure Sci. 19:129-146.

TUZEN M. and SOYLAK, M. 2007. Evaluation of trace element contents in canned food marketed from Turkey. Food Chemistry, 102: 1089-1095.

ULUTURHAN, E. and KUCUKSEZGIN, F. 2007. Heavy metal contaminants in Red Pandora (Pagellusery thrinus) tissues from the eastern Aegean Sea Turkey. Water Res 41: 1185-1192.

USFDA. 1993. Food and drug administration. Guidance document for nickel in shellfish. Office of Seafood, Washington, DC.

WAALKES, M.P. 2000. Cadmium carcinogenesis in review. Journal of inorganic biochemistry, 79(1-4), 241-244.

(Manuscript received on 19 April, 2019; revised on 3 November, 2019) 